\title{
Phytosensitization and Cytotoxic Studies of Anacardium occidentale L. on Cancer Cell Lines - A Herbaceutical Approach
}

\author{
Amar Shankar $^{1}$, S. M. Gopinath ${ }^{2 *}$ and M. Ismail Shareef ${ }^{1}$ \\ ${ }^{1}$ Department of Biotechnology, Acharya Institute of Technology, Acharya Doctor Sarvepalli \\ Radhakrishnan Rd, Soladevanahalli, Karnataka, India- 560107 \\ ${ }^{2}$ Department of Biotechnology, Davangere University, Shivagangotri, Davangere, Karnataka, \\ India- 577002 \\ *Corresponding author
}

\section{A B S T R A C T}

\section{Keywords}

\section{Anacardium} occidentale, Anticancer, Antioxidant, Cytotoxic, In vitro, In silico, MAP kinase

Article Info

Accepted: 08 January 2020 Available Online: 10 February 2020
Phytobioactives have been proved to be effective on various ailments and diseases. The same logic is been used by many traditional healers and practitioners and is evident from ancient scripts of Ayurveda. One such, less explored plant is Anacardium occidentale L., (Anacardiaceae). The phenolics from the leaves and bark have been partially explored in folklore medicine but the probable mode of action is still unclear. Hence the current study aims at the exploration of the anti-cancer potency of phytobioactives from Anacardium occidentale. Qualitative phytochemical profiling of the leaves and bark, followed by polarity based hot extraction procedure (hexane, ethyl acetate, methanol), In vitro antioxidant studies (ABTS, nitric oxide, reducing power radical assays) and cytotoxic studies were performed on six cell lines (Vero, L929, A549, MCF 7, U87 and Hela). The probable mode of action on p38 $\alpha$ MAP kinase was proposed based on In silico molecular docking structure-activity relationship (SAR) studies wherein partially purified fractions predominately contained zoapatanolide A (diterpenoid), a gas this flav one (biflavonoid) and anacardic acid (phenolic acid) were considered, out of which a gas this flav one had an atomic contact energy (ACE) values of -345.06 than compared to the standard drug doxorubicin (-409.14). The results of the current study inferred the potency of the herbal cocktail as antioxidant and being functional against cancer cell lines (ethyl acetate fraction). Further, studies could be extrapolated for the purification of the active ingredients from Anacardium occidentale in search for potent, newer therapeutics.

\section{Introduction}

Cancer is one of the most deadly diseases of the $20^{\text {th }}$ century further increasing its incidence in the $21^{\text {st }}$ century, due to change in lifestyle, habits and majorly due to genetic mutations. The global cancer statistics of
2018, estimate that there are 18.1 million new cancer cases and 9.6 million cancer deaths (Bray et al., 2018). Whereas in India, there are about 2.25 million people recorded and suffering from the disease with $7,84,821$ death due to cancer alone, according to National institute of cancer prevention and 
Research. The five major types of cancer include carcinoma, sarcoma, lymphoma, melanoma and leukemia among which carcinoma is the cancer that is the most diagnosed. Carcinomas are mainly observed in the lungs, breasts, skin, glands and pancreas. Lung cancer is one of the most frequent that leads to countless number of deaths worldwide. Cancer is treated through surgery, chemotherapy, hormonal therapy, radiation therapy and immunotherapy (Bhavani et al., 2013). Drawbacks of these therapies are they are not cost effective; they cause side effects with physical and mental trauma, frequent visits to the hospital is necessary and becomes evitable. Due to cancer condition the immune system produces high amounts of free radicals that lead to oxidative stress, blocking the repair cascades, cellular damage which will further lead into an immune-compromised condition.

Injuries due to oxidative stress accumulate over time and enhance the development of cancer. Oxygen, sulfur and nitrogen are the three key molecules from which free radicals originate forming reactive oxygen species, reactive sulfur species and reactive nitrogen species respectively (Aslani et al., 2016). As per previous studies high expression of $\mathrm{p} 38 \alpha$ MAP kinase is highly expressed in cancer (Kamelia et al., 2017) therefore targeting MAPK/ERK (mitogen activated protein kinase/ extracellular signal regulated kinase) pathway acts as a cure for cancer. MAP kinase is an ATP and $\mathrm{Mg}^{2+}$ dependent pathway, when the antigen binds to receptor tyrosine kinase (RTK) that is present in the cellular membrane and undergoes autophosphorylation activating RAS protein. RAS protein is GTP dependent, active RAS will activate RAF protein, two RAF molecules will bind together to form an activated RAF dimer. The dimer activates MEK1/2 protein this in turn activates ERK/MAPK in the cytoplasm. The cytoplasmic ERK/MAPK has the ability to enter the nuclear membrane that activates gene transcription and enhances the growth of the cells and helps them for its survival.

To overcome all these consequences, targeting ERK/MAP kinase and inhibiting them would aid in the treatment of cancer and therefore, the use of phytomolecules that has an anti-oxidant property (Ashwini et al., 2019; Praveen et al., 2018), antiinflammatory (Madhusudan et al., 2015; Sathya et al., 2016) and exhibits anticancer activity (Gezici and Sekeroglu, 2019; Sathya et al., 2014).

To screen the phytomolecules present in plants, the extensively used folklore anticancer plant Anacardium occidentale L. was chosen since it was less explored and is profoundly used by the tribal healers. Anacardium occidentale commonly known as cashew is an evergreen tropical shrub that grows up to 15 meters tall belonging to the family Anacardiaceae. Cashews are rich in vitamin $B_{2}$, vitamin $B_{3}$, vitamin $C$, vitamin $E$, magnesium and pantothenic acid. Proanthocyanidins is a class of flavonoids present in cashew that prevent the cancer cells from further dividing and spreading throughout the body. The fruit of the plant is used in the production of juice and dietary fibbers.

The fruit consists of two main parts, the fruit itself that is the chestnuts and the pseudo-fruit that is used in the production of juice (Da Silva et al., 2013). Biological components such as polyphenols, flavonoids, carotenoids, vitamin $\mathrm{C}$ and vitamin $\mathrm{A}$ are present in the fruit. The biological components that are present in the powdered leaf extract and Cashew nut shell liquid in a large quantity is found to be Zoapatanolide A, diterpenoid, Agasthisflavone, biflavonoid and anacardic acid, polyphenol (Salehi et al., 2019) 
respectively (Fig. 1). These phytomolecules (Table 1) were partially fractionated based on polarity and were used to study their antioxidant, anticancer and structure-activity relationship studies. The current study was designed to explore the phytosensitization and cytotoxic potential of Anacardium occidentale based on bioactivity-guided approach finally to justify the mode of action of the plant extract extensively used by the traditional practitioners/herbal healers.

\section{Materials and Methods}

All chemicals and solvents used were of analytical grade and were procured from Merck India Pvt. Ltd, Mumbai.

\section{Preparation of the plant material for the extraction}

Anacardium occidentale L., plant was identified with the help of Botanist and the voucher specimen was labelled (FRLH: 120174: 31.03.2017). The plant sample of leaves and bark were powdered and stored. Continuous hot successive extraction process by using soxhlet apparatus was carried out. The plant powder was subjected for Soxhlet extraction in round bottomed flask with Hexane $(2.0 \mathrm{lts})$ for $12 \mathrm{~h}$. The extract was concentrated under reduced pressure at 50$60^{\circ} \mathrm{C}$ till complete drying. The dried successive Hexane extract (yield $10 \mathrm{~g}, 4 \%$ ) was stored in a closed vessel at $4^{\circ} \mathrm{C}$ in a refrigerator till further use. The Hexane extracted root extract was dried and once again subjected to Soxhlet extraction successively with different solvents viz., ethyl acetate and methanol ( 2 lts each). The extracts were concentrated and stored as described above. The yields were calculated in percentage. The successive extracts were stored in closed vessels at $4{ }^{\circ} \mathrm{C}$ in a refrigerator till further use.

\section{Preliminary phytochemical analysis}

All the qualitative phytochemical profiling was performed as per the procedure explained by Nupur et al., 2013.

\section{Test of carbohydrates}

$500 \mathrm{mg}$ of extract was dissolved in $5 \mathrm{ml}$ of distilled water and filtered. The filtrate was used to test the presence of carbohydrates (Rosenthaler, 1930).

\section{Molisch's test}

Molish reagent: $10 \mathrm{gm}$ of alpha napthol was dissolved in $100 \mathrm{ml}$ of $95 \%$ methanol to prepare Molish reagent

To the extract, two drops of Molish reagent and few drops of concentrated $\mathrm{H}_{2} \mathrm{SO}_{4}$ is added, formation of purple-violet ring indicates the presence of carbohydrates.

\section{Detection of Glycosides}

$0.5 \mathrm{gm}$ of the extract was hydrolyzed with 20 $\mathrm{ml}$ of $\mathrm{HCl}(0.1 \mathrm{~N})$ and filtered. The filterate was used to test the presence of Glycosides (Ronsenthaler 1930; Middeltone, 1956).

\section{Keller-Killiani test}

To the extract, few drops of glacial acetic acid and one drop of $5 \% \mathrm{FeCl}_{3}$ and concentrated $\mathrm{H}_{2} \mathrm{SO}_{4}$ were added, formation of reddish brown colour at the junction of two liquid layers and upper layer turned bluish green indicates the presence of glycosides.

\section{Detection of Saponins}

\section{Foam test}

$1 \mathrm{ml}$ of extract was diluted to make up to 20 $\mathrm{ml}$ with distilled water and slowly shake in a 
graduated cylinder for 15 minutes. One $\mathrm{cm}$ layer of foam indicates the presence of saponins (Kokate, 2001).

\section{Detection of alkaloids}

$0.5 \mathrm{gm}$ of the extract was dissolved in $10 \mathrm{ml}$ of dilute $\mathrm{HCl}(0.1 \mathrm{~N})$ and filtered. The filtrate was used to test the presence of alkaloids (Rosenthaler, 1930; Peach and Trancey, 1955).

\section{Mayer's test}

Mayer's reagent: readily available from $\mathrm{Sd}$ fine chemicals, Mumbai.

Filtrate was treated with Meyer's reagent; formation of yellow cream colored precipitate indicates the presence of alkaloids.

\section{Dragendorff's test}

\section{Dragendorff's reagent}

i) Dissolve $8 \mathrm{gm}$ of bismuth subnitrate in 20 $\mathrm{ml}$ of nitric acid.

ii) Dissolve $27.2 \mathrm{gm}$ of Potassium iodide in $50 \mathrm{ml}$ of distilled water, mix (a) and (b) and adjust the volume to $100 \mathrm{ml}$ with distilled water.

Filtrate was treated with Dragendorff's reagent; formation of red colored precipitate indicates the presence of alkaloids.

\section{Detection of flavonoids}

\section{Alkaline reagent test}

To $100 \mathrm{mg}$ of extract, few drops of $\mathrm{NaOH}$ solution were added in a test tube. Formation of intense yellow color that becomes colorless on addition of few drops of dilute $\mathrm{HCl}$ indicates the presence of Flavonoids (Shellard, 1957).

\section{Detection of phenolics and tannins}

$100 \mathrm{mg}$ of extract was boiled with $1 \mathrm{ml}$ of distilled water and filtered (Kokate, 2001). The filtrate was used for the following test.

\section{Ferric chloride test}

To $2 \mathrm{ml}$ of filtrate, $2 \mathrm{ml}$ of $1 \%$ ferric chloride solution was added in a test tube. Formation of bluish black color indicates the presence of phenolic nucleus.

\section{Test for Tannins}

To the extract $0.5 \mathrm{ml} \mathrm{NaOH}$ was added, formation of precipitate indicates the presence of tannins.

\section{Detection of phytosterols and triterpenoids}

$0.5 \mathrm{gm}$ of extract was treated with $10 \mathrm{ml}$ chloroform and filtered. The filtrate was used to test the presence of Phytosterols and Triterpenoids (Paech and Tracey, 1955).

\section{Liebermann's test}

To $2 \mathrm{ml}$ of filtrate in hot alcohol, few drops of acetic anhydride were added. Formation of brown precipitate indicates the presence of sterols.

\section{Liebermann- Burchard test}

To the extract, few drops of acetic acid and concentrated $\mathrm{H}_{2} \mathrm{SO}_{4}$ were added, deep red ring at the junction of two layers indicates the presence of triterpenes.

\section{Salkowski test}

To the extract solution few drops of Conc. Sulphuric acid was added and shaken and allowed to stand, lower layer turns red indicating the presence of sterols. 


\section{Detection of fixed oils and fats}

\section{Oily spot test}

One drop of extract was placed on filter paper and solvent was allowed to evaporate. An oily stain on filter paper indicates the presence of fixed oil (Ronsenthaler, 1930).

\section{In vitro antioxidant assay}

The crude extracts of leaves and bark of Anacaridium occidentale were evaluated for in-vitro antioxidant activity by ABTS radical assay, Nitric oxide radical assay and Reducing Power Assay with concentrations ranging from $1000-6.25 \mu \mathrm{g} / \mathrm{ml}$.

\section{ABTS radical scavenging assay}

The standards were prepared by adding $0.95 \mathrm{ml}$ of methanol, $10 \mathrm{mg}$ of rutin was dissolved to obtain stock of $10.5 \mathrm{mg} / \mathrm{ml}$ concentration. The stock solution was serially diluted to get lower concentrations $(0.625$, $1.25,2.5,5$ and $10 \mu \mathrm{g} / \mathrm{ml})$. The test sample was prepared in $1 \mathrm{ml}$ of methanol, $21 \mathrm{mg}$ of test substances were dissolved to obtain stock of $21 \mathrm{mg} / \mathrm{ml}$ concentration. The stock solutions were serially diluted to get lower concentrations $(62.5,125,250,500$ and 1000 $\mu \mathrm{g} / \mathrm{ml})$. Further, the inhibition was assayed in $5 \mathrm{ml}$ of distilled water, $5.48 \mathrm{mg}$ of $2,2^{\prime}$ AzinoBis [3-ethylbenzoThiazoline-6-Sulfonic acid]-diammonium salt (ABTS) $2 \mathrm{mM}$ and $0.03 \mathrm{ml}$ potassium persulphate $(17 \mathrm{mM}$,) were dissolved. The reaction mixture was left to stand at room temperature overnight in dark and freshly prepared solution was used for each trail. To $0.2 \mathrm{ml}$ of various concentrations of the test substances or standards, $1.0 \mathrm{ml}$ of PBS and $0.16 \mathrm{ml}$ of ABTS solution were added to get a final volume of $1.36 \mathrm{ml}$ in eppendorf tubes and mixed using cyclomixer. The same step is repeated for test blank and control blank, instead of ABTS reagent, 0.16 $\mathrm{ml}$ of distilled water was taken. After 20 minutes of incubation, $0.1 \mathrm{ml}$ of reaction mixture was pipetted to microtitre plate in triplets for test, control and singlet for test blank and control blank. The absorbance in ELISA reader at $734 \mathrm{~nm}$ was measured and the values were recorded.

\section{Nitric oxide assay}

In $1 \mathrm{ml}$ of DMSO (Dimethyl sulfoxide), $21 \mathrm{mg}$ of test substances were dissolved to obtain stock of $21 \mathrm{mg} / \mathrm{ml}$ concentration. The stock solutions were serially diluted to get lower concentrations $(62.5,125,250,500$ and 1000 $\mu \mathrm{g} / \mathrm{ml})$. The standards were prepared by adding $0.95 \mathrm{ml}$ of DMSO, $10 \mathrm{mg}$ of ascorbic acid was dissolved to obtain stock of $10.5 \mathrm{mg} / \mathrm{ml}$ concentration. The stock solution was serially diluted to get lower concentrations $(62.5,125,250,500$ and 1000 $\mu \mathrm{g} / \mathrm{ml})$. Briefly, for the assay sodium nitroprusside $(10 \mathrm{mM}, 0.4 \mathrm{ml})$, phosphate buffer saline (PBS, pH 7.4, $0.1 \mathrm{ml}$ ) and $0.1 \mathrm{ml}$ of test substances or standard of various concentrations were incubated at $25^{\circ} \mathrm{C}$ for 150 minutes. DMSO of $0.1 \mathrm{ml}$ was used for control and control blank. In place of sodium nitroprusside, distilled water is taken for test blank and control blank.

Followed by incubation, $0.05 \mathrm{ml}$ of the reaction mixture containing nitrite ion was pipetted out from centrifuge tubes into microtiter plate in triplets for test and control. Control blank and test blank were taken in singlet. $0.1 \mathrm{ml}$ of sulphanilic acid reagent was added to all the wells, mixed and allowed to stand for 5 minutes for completion of diazotization. Then, $0.1 \mathrm{ml}$ of Naphthyl Ethylene Diamine Dihydrochloride (NEDD) was added and allowed to stand for 30 minutes in diffused light. The absorbance of these solutions was measured at $540 \mathrm{~nm}$ using ELISA reader. 


\section{Reducing power assay}

The sample was prepared by adding $1 \mathrm{ml}$ of DMSO, $10 \mathrm{mg}$ of test substances were dissolved to obtain stock of $10 \mathrm{mg} / \mathrm{ml}$ concentration. The stock solutions were serially diluted to get lower concentrations $(62.5,125,250,500$ and $1000 \mu \mathrm{g} / \mathrm{ml})$. The standards were of prepared by adding $0.95 \mathrm{ml}$ of DMSO, $10 \mathrm{mg}$ of quercitin was dissolved to obtain stock of $10.5 \mathrm{mg} / \mathrm{ml}$ concentration. The stock solution was serially diluted to get lower concentrations $(62.5,125,250,500$ and $1000 \mu \mathrm{g} / \mathrm{ml}$ ). Briefly, $0.5 \mathrm{ml}$ the test samples or standard, $2 \mathrm{ml}$ of phosphate buffer $(0.2 \mathrm{M}$, $\mathrm{pH}$ 6.6) and $2.5 \mathrm{ml}$ of $1 \%$ potassium ferric cyanide is added. In place of potassium ferric cyanide, distilled water is taken for test blank and control blank. The reaction mixture is kept at $50^{\circ} \mathrm{C}$ water-bath for 30 minutes. The resulting solution was then cooled to room temperature and $2.5 \mathrm{ml}$ of $10 \%$ trichloroacetic acid was added. Centrifuge at $3000 \mathrm{rpm}$ for 10 minutes. To $5 \mathrm{ml}$ of supernatant, $5 \mathrm{ml}$ of distilled water and $1 \mathrm{ml}$ of $0.1 \%$ ferric chloride was added and kept for incubation for 10 minutes. $0.1 \mathrm{ml}$ is pipetted out to microtiter plate i.e., test and control in triplets and test blank and control blank in singlet. The absorbance was read at $700 \mathrm{~nm}$ using ELISA reader and the values were noted. The reducing power assay was expressed in terms of Ascorbic acid equivalent per gram of dry weight basis.

\section{Cytotoxicity studies and Determination of mitochondrial synthesis by MTT assay}

Briefly the method of Francis and Rita; 1986 was followed. Wherein, monolayer cell culture was trypsinized and the cell count was adjusted to $1.0 \times 10^{5}$ cells $/ \mathrm{ml}$ using Ham's F12 medium containing $10 \%$ FBS. To each well of a 96 well microtitre plate, $100 \mu \mathrm{l}$ of the diluted cell suspension (approximately 10,000 cells/well) was added. After 24 hours, when a partial monolayer was formed, the supernatant was flicked off, the monolayer was washed once with medium and $100 \mu$ of different plant extract concentrations prepared in maintenance media were added per well to the partial monolayer in microtitre plates. The plates were then incubated at $37^{\circ} \mathrm{C}$ for 3 days in $5 \% \quad \mathrm{CO}_{2}$ atmosphere, and microscopic examination was carried out and observations recorded every 24 hours. After 72 hours, the plant extract solutions in the wells were discarded and $50 \mu \mathrm{l}$ of MTT $(2 \mathrm{mg} / \mathrm{ml})$ in MEM-PR (MEM without phenol red) was added to each well. The plates were gently shaken and incubated for 4 hours at $37^{\circ} \mathrm{C}$ in $5 \% \quad \mathrm{CO}_{2}$ atmosphere. The supernatant was removed and $50 \mu$ of isopropanol was added and the plates were gently shaken to solubilize the formed formazan. The absorbance was measured using a microplate reader at a wavelength of $540 \mathrm{~nm}$. The percentage growth inhibition was calculated using the following formula [ $(\%$ Growth Inhibition $=100-($ Mean OD of individual test group/ Mean OD of control group) x 100] and concentration of drug or test extract needed to inhibit cell growth by $50 \%$ values were generated from the dose-response curves for each cell line.

\section{Molecular Docking Studies}

Molecular docking studies were performed to understand the structure-activity relationship of the top three potent inhibitors isolated from Anacardium occidentale. The phytomolecules (ligands) were docked into the active site of p38 $\alpha$ MAP kinase (target) using a molecular docking software PATCH Dock. It is an algorithm that is used to calculate the docking modes of small molecules into the active sites based on the shape complementarity. Molecular docking of the molecules revealed the atomic contact energy (ACE) and the amino acid binding residues that are as depicted in Table 1. The structures of the 
ligands were constructed using Dundee PRODRG server (Thomsen et al., 2006) which reduces the energy and standardizes the conformation of the side chains. The precise location of the binding site and the potentiality of the ligand to bind to the active site were determined using an automated docking software, molegro virtual docker 2008, version 3.2.1 (Molegro ApS, Aarhus, Denmark, http:// molegro.com), that is based on guided differential evolution and a force filed based screening function (Schuttelkopf et al., 2004). With the help of Clustering methods the possible binding conformations and orientations were determined. The enzyme was visualized using the sequence option. The binding site was calculated within a spacing range so that the binding site was well sampled with a grid resolution of $0.3 \AA$. Using MolDock optimizer algorithm the ligand was docked into the grid and the interactions were analyzed using detailed energy estimates (Rakesh et al., 2016). A maximum population of 100 and maximum interactions of 10,000 were used for each run and the five best poses were retained. The software was utilized to identify hydrogen bonds and hydrophobic interactions between residues at the active site and the ligand.

\section{Results and Discussion}

Anacardium occidentale L., was collected and the vegetative parts mainly the leaves and bark were powered and subjected to successive solvent extraction with hexane, ethyl acetate and methanol. The extracts were subjected to qualitative phytochemical analysis. The results of the profiling exhibited predominately the presences of polyphenols, phenolic acids, flavonoids, triterpenoids and phytosterols mainly in ethyl acetate leaves and bark (Table 2). These classes of phytobioactives are found to have various bioactivities ranging from antimicrobes, antidiabetic, anti-inflammatory, hepatoprotective and anticancer (Salehi et al., 2019).

Further, according to Hans hypothesis (1984) oxidants are the prime culprits for all disorders and diseases. Hence exploring an ideal antioxidant phytoprinciple will be of importance in terms of developing newer functional foods and neutraceuticals. Free radicals are found to be the major cause for ionic dysbiosis. Striking a right balance by quenching the free radical would be possible by potent and effective antioxidants.

Hence current study aimed at exploring Anacardium occidentale phytobioactives by in vitro antioxidant assays were performed by ABTS, nitric oxide and reducing power radical scavenging activity and their respective $\mathrm{IC}_{50}$ were calculated (Table 3 ). From the ABTS results, ethyl acetate leaves fraction was proved to be potent with $\mathrm{IC}_{50}=$ $22.39 \mu \mathrm{g} / \mathrm{mL}$ compared to methanol and hexane extract respectively. However, the bark fraction methanol extract was found to be potent with an $\mathrm{IC}_{50}=17.35 \mu \mathrm{g} / \mathrm{mL}$ followed by moderately potent with ethyl acetate and hexane fraction. Further, the Nitric oxide and reducing power assay in the leaf fraction, the same trend was observed with $\mathrm{IC}_{50}=91.81 \mu \mathrm{g} / \mathrm{mL}$ and 3.5 fold reducing power potential respectively, then compared to methanol and hexane fractions. In bark extract, ethyl acetate, methanol and hexane trend was observed respectively (Table 3). To examine the effect of these phytomolecules to treat cancer, we used MCF-7, U87, Vero, A549, HeLa and L929 cancer cell lines respectively which were procured from National Center for Cell Sciences (NCCS), Pune. Cell lines are widely used as in vitro models of tumorigenesis, for cancer pharmacogenomic studies and to study the novel mechanism of drug response (Niu et al., 2015). Originally, MCF-7 cells were isolated from a Caucasian woman, these 
cancer cell lines are used as models for breast cancer. U87 was isolated from glioblastoma cells from a 44 year old patient these cells were used as a model to treat glioblastoma. Vero cells are epithelial cells isolated from the kidney of an African green monkey, these cell lines are used to treat viral diseases.

A549 are cell lines that are used as models for lung cancer these are adenocarcinomic human alveolar basal epithelial cells isolated from a Caucasian male. L929 is a cancer cell line isolated from an old male $\mathrm{C} 3 \mathrm{H} /$ mouse, these cell lines are used to determine the anti-cancer activity. The ability of the cells to survive a toxic insult has been the basis of most cytotoxicity assays. This assay is based on the assumption that dead cells or their products do not reduce tetrazolium. The assay depends both on the number of cells present and on the mitochondrial activity per cell. The cleavage of MTT to a blue formazan derivative by living cells is clearly a very effective principle on which the assay is based.

The principle involved is the cleavage of tetrazolium salt MTT (3-(4,5 dimethyl thiazole-2 yl)- 2,5-diphenyl tetrazolium bromide) into a blue coloured product (formazan) by mitochondrial enzyme succinate dehydrogenase. The numbers of cells were found to be proportional to the extent of formazan production by the cells used. The results inferred that, cytotoxicity was predominately effective on cancer cell lines mainly by the ethyl acetate leaves fraction (Table 4). Briefly, on normal cell lines namely Vero and L929 reduced cell death was observed which proves to be less toxic however, the ethyl acetate leaves fraction significantly exhibited cytotoxicity on U87, MCF-7, Hela and A549 cell lines respectively with an average $\mathrm{CTC}_{50}=107.75$ $\mu \mathrm{g} / \mathrm{mL}$. Further, the bark ethyl acetate extract was also potential with average $\mathrm{CTC}_{50}=$ $209.21 \mu \mathrm{g} / \mathrm{mL}$ respectively (Table 4 ). Hexane and methanol fraction in both leaves and bark exhibited moderate to minimal activity.

Docking studies was performed to obtain the preliminary data using the screened phytomolecules as ligands and p38- $\alpha$ MAPK (p38- $\alpha$ mitogen-activated protein kinase) as the target molecule.

Table.1 List of major phytochemical molecules present in Anacardium occidentale L.

\begin{tabular}{|c|c|c|c|}
\hline Plant part & Compound/Ligands & Biological activity & References \\
\hline \multirow{4}{*}{$\begin{array}{c}\text { Powdered leaf } \\
\text { extract }\end{array}$} & Zoapatanolide A & \multirow{4}{*}{$\begin{array}{l}\text { Polyphenolic } \\
\text { ethanolic extract - } \\
\text { Anti-cancer }\end{array}$} & \multirow{4}{*}{$\begin{array}{l}\text { Taiwo et al., } \\
2017\end{array}$} \\
\hline & Agathisflavone & & \\
\hline & $\begin{array}{l}\text { Anacardicin (1,2-bis(2,6- } \\
\text { dimethoxy-4- } \\
\text { methoxycarbonylpheny) ethane) }\end{array}$ & & \\
\hline & Methyl gallate & & \\
\hline $\begin{array}{l}\text { CNSL (cashew nut } \\
\text { shell liquid, } \\
\text { pericarp, } \\
\text { byproduct) }\end{array}$ & $\begin{array}{l}\text { Anacardic acid-1,2,3,4 } \\
\text { Cardol-1,2 } \\
\text { Cardanol-1,2,3,4 } \\
\text { Methyl cardol }\end{array}$ & $\begin{array}{l}\text { Polyphenolic } \\
\text { methanolic extract- } \\
\text { anti-bacterial } \\
\text { wound healing, \& } \\
\text { anti-oxidant }\end{array}$ & $\begin{array}{l}\text { Ashraf \& } \\
\text { Rathinasamy; } \\
2018\end{array}$ \\
\hline $\begin{array}{l}\text { CNSL (cashew nut } \\
\text { shell liquid only) }\end{array}$ & Cardanol Monoene & $\begin{array}{l}\text { Polyphenolic } \\
\text { methanolic extract- } \\
\text { Anti-cancer }\end{array}$ & Su et al., 2017 \\
\hline
\end{tabular}


Table.2 Preliminary phytochemical tests for AoL and AoB Extract

\begin{tabular}{|c|c|c|c|c|c|c|c|}
\hline SI. No & Test & $\begin{array}{l}\text { AoL } \\
\text { Hexane } \\
\text { Extract }\end{array}$ & $\begin{array}{l}\text { AoL } \\
\text { Ethyl } \\
\text { acetate } \\
\text { Extract }\end{array}$ & $\begin{array}{l}\text { AoL } \\
\text { Methanol } \\
\text { Extract }\end{array}$ & $\begin{array}{l}\text { AoB } \\
\text { Hexane } \\
\text { Extract }\end{array}$ & $\begin{array}{l}\text { AoB } \\
\text { Ethyl } \\
\text { acetate } \\
\text { Extract }\end{array}$ & $\begin{array}{l}\text { AoB } \\
\text { Methanol } \\
\text { Extract }\end{array}$ \\
\hline 1 & $\begin{array}{l}\text { Test for Carbohydrates } \\
\text { a. Molisch's test }\end{array}$ & - & - & - & - & + & + \\
\hline 2 & $\begin{array}{l}\text { Test for Glycosides } \\
\text { a. Keller-Killiani test }\end{array}$ & - & - & - & - & + & + \\
\hline 3 & $\begin{array}{l}\text { Test for Saponins } \\
\text { a. Foam test }\end{array}$ & - & - & + & - & - & + \\
\hline 4 & $\begin{array}{l}\text { Test for Alkaloids } \\
\begin{array}{l}\text { a. Mayer's test } \\
\text { b. Dragendrodroff's } \\
\text { test }\end{array}\end{array}$ & - & $\begin{array}{l}- \\
-\end{array}$ & $\begin{array}{l}- \\
-\end{array}$ & - & - & - \\
\hline 5 & $\begin{array}{l}\text { Test for Flavonoids } \\
\text { Alkaline reagent test }\end{array}$ & - & + & + & - & + & - \\
\hline 6 & $\begin{array}{l}\text { Test for Phenolics and } \\
\text { Tannins } \\
\text { a. Ferric chloride test } \\
\text { b. Test for Tannins }\end{array}$ & - & $\begin{array}{l}+ \\
-\end{array}$ & $\begin{array}{l}+ \\
-\end{array}$ & - & $\begin{array}{l}+ \\
-\end{array}$ & $\begin{array}{l}+ \\
-\end{array}$ \\
\hline 7 & $\begin{array}{l}\text { Test for Phytosterols and } \\
\text { Triterpenoids } \\
\begin{aligned} \text { a. Leiberman- } \\
\text { Bucharat test } \\
\text { b. Salkowaski test }\end{aligned}\end{array}$ & - & $\begin{array}{l}+ \\
+\end{array}$ & $\begin{array}{l}+ \\
+\end{array}$ & $\begin{array}{l}+ \\
+\end{array}$ & $\begin{array}{l}+ \\
+\end{array}$ & - \\
\hline 8 & $\begin{array}{l}\text { Test for fixed oils and } \\
\text { fats } \\
\text { a. Oily spot test }\end{array}$ & - & - & - & - & - & - \\
\hline
\end{tabular}

Footnote: (+) Present, (-) Absent 
Table.3 In vitro free radical screening assays for Anacaridium occidentale leaves-AoL and Bar- AoB

\begin{tabular}{|c|c|c|c|c|c|c|c|c|}
\hline $\begin{array}{l}\text { Sl. } \\
\text { no }\end{array}$ & Extract & Sample & $\begin{array}{c}\text { Conc. } \\
\mu \mathrm{g} / \mathrm{mL}\end{array}$ & $\begin{array}{l}\text { ABTS radical } \\
\text { \% Inhibition }\end{array}$ & $\begin{array}{c}\text { ABTS } \\
\text { radical } \mathrm{IC}_{50} \\
\text { in } \mu \mathrm{g} / \mathrm{mL}\end{array}$ & $\begin{array}{l}\text { Nitric oxide } \\
\text { radical } \\
\% \\
\text { Inhibition }\end{array}$ & $\begin{array}{l}\text { Nitric oxide } \\
\text { radical } \mathrm{IC}_{50} \\
\text { in } \mu \mathrm{g} / \mathrm{mL}\end{array}$ & $\begin{array}{c}\text { Reducing Power } \\
\text { Absorbance @ } 700 \\
\text { nm }\end{array}$ \\
\hline \multirow[t]{5}{*}{1.} & \multirow{10}{*}{ 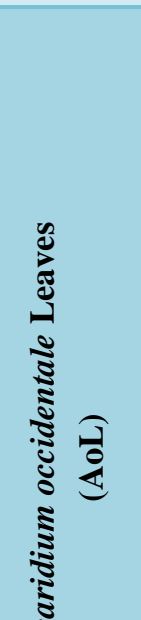 } & \multirow[t]{5}{*}{ Hexane } & 1000 & $96.97 \pm 0.46$ & \multirow{5}{*}{$\underset{0.28}{206.31} \pm$} & $69.16 \pm 1.01$ & \multirow[t]{5}{*}{$328.66 \pm 0.35$} & $0.161 \pm 0.002$ \\
\hline & & & 500 & $76.72 \pm 0.11$ & & $55.63 \pm 0.62$ & & $0.157 \pm 0.002$ \\
\hline & & & 250 & $53.13 \pm 0.10$ & & $47.43 \pm 0.17$ & & $0.146 \pm 0.001$ \\
\hline & & & 125 & $44.15 \pm 0.57$ & & $42.53 \pm 0.46$ & & $0.139 \pm 0.001$ \\
\hline & & & 62.5 & $19.28 \pm 0.66$ & & $34.17 \pm 0.39$ & & $0.124 \pm 0.001$ \\
\hline \multirow[t]{5}{*}{2} & & \multirow{5}{*}{$\begin{array}{c}\text { Ethyl } \\
\text { acetate }\end{array}$} & 1000 & $99.59 \pm 0.18$ & \multirow{5}{*}{$22.39 \pm 0.21$} & $79.45 \pm 0.39$ & \multirow{5}{*}{$91.81 \pm 0.16$} & $0.417 \pm 0.006$ \\
\hline & & & 500 & $66.45 \pm 0.15$ & & $76.99 \pm 0.44$ & & $0.286 \pm 0.001$ \\
\hline & & & 250 & $53.39 \pm 0.51$ & & $64.27 \pm 0.40$ & & $0.254 \pm 0.001$ \\
\hline & & & 125 & $37.18 \pm 0.27$ & & $53.37 \pm 0.21$ & & $0.177 \pm 0.004$ \\
\hline & & & 62.5 & $31.06 \pm 0.52$ & & $47.02 \pm 0.08$ & & $0.154 \pm 0.002$ \\
\hline \multirow[t]{5}{*}{3} & \multirow{5}{*}{ 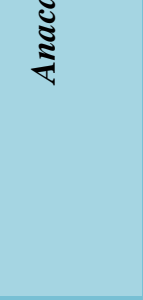 } & \multirow[t]{5}{*}{ Methanol } & 1000 & $98.39 \pm 0.35$ & \multirow[t]{5}{*}{$74.20 \pm 0.18$} & $89.99 \pm 0.09$ & \multirow[t]{5}{*}{$230.16 \pm 0.36$} & $1.067 \pm 0.023$ \\
\hline & & & 500 & $97.94 \pm 0.94$ & & $68.96 \pm 0.07$ & & $0.631 \pm 0.002$ \\
\hline & & & 250 & $92.23 \pm 0.50$ & & $53.06 \pm 0.29$ & & $0.370 \pm 0.001$ \\
\hline & & & 125 & $63.89 \pm 0.38$ & & $33.74 \pm 0.67$ & & $0.273 \pm 0.002$ \\
\hline & & & 62.5 & $46.79 \pm 0.38$ & & $26.91 \pm 0.89$ & & $0.139 \pm 0.003$ \\
\hline \multirow[t]{5}{*}{4} & \multirow{15}{*}{ 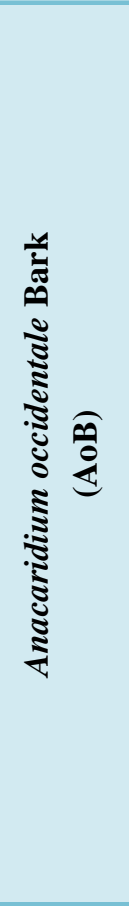 } & \multirow[t]{5}{*}{ Hexane } & 1000 & $98.56 \pm 0.16$ & \multirow{5}{*}{$\begin{array}{c}234.90 \\
0.32\end{array}$} & $68.43 \pm 0.16$ & \multirow[t]{5}{*}{$245.98 \pm 0.37$} & $0.165 \pm 0.005$ \\
\hline & & & 500 & $91.76 \pm 0.08$ & & $60.09 \pm 0.45$ & & $0.148 \pm 0.001$ \\
\hline & & & 250 & $53.02 \pm 0.05$ & & $50.58 \pm 0.20$ & & $0.140 \pm 0.001$ \\
\hline & & & 125 & $27.98 \pm 0.60$ & & $32.45 \pm 0.35$ & & $0.129 \pm 0.002$ \\
\hline & & & 62.5 & $22.90 \pm 0.77$ & & $23.89 \pm 1.05$ & & $0.112 \pm 0.006$ \\
\hline \multirow[t]{5}{*}{5} & & \multirow{5}{*}{$\begin{array}{c}\text { Ethyl } \\
\text { acetate }\end{array}$} & 1000 & $98.47 \pm 0.10$ & \multirow[t]{5}{*}{$96.43 \pm 0.16$} & $62.88 \pm 0.53$ & \multirow{5}{*}{$149.87 \pm 0.24$} & $0.572 \pm 0.001$ \\
\hline & & & 500 & $97.60 \pm 0.09$ & & $56.52 \pm 0.06$ & & $0.389 \pm 0.000$ \\
\hline & & & 250 & $84.69 \pm 0.29$ & & $52.42 \pm 0.14$ & & $0.276 \pm 0.001$ \\
\hline & & & 125 & $55.53 \pm 0.46$ & & $49.35 \pm 0.49$ & & $0.211 \pm 0.004$ \\
\hline & & & 62.5 & $43.43 \pm 0.17$ & & $39.25 \pm 0.04$ & & $0.180 \pm 0.003$ \\
\hline \multirow[t]{5}{*}{6} & & \multirow[t]{5}{*}{ Methanol } & 1000 & $98.79 \pm 0.41$ & \multirow[t]{5}{*}{$17.35 \pm 0.21$} & $71.50 \pm 0.24$ & \multirow[t]{5}{*}{$208.39 \pm 0.47$} & $0.798 \pm 0.005$ \\
\hline & & & 500 & $82.06 \pm 0.36$ & & $62.10 \pm 0.23$ & & $0.521 \pm 0.006$ \\
\hline & & & 250 & $69.62 \pm 0.75$ & & $58.10 \pm 0.27$ & & $0.332 \pm 0.001$ \\
\hline & & & 125 & $37.58 \pm 0.69$ & & $33.72 \pm 1.33$ & & $0.247 \pm 0.002$ \\
\hline & & & 62.5 & $30.57 \pm 0.83$ & & $26.47 \pm 0.53$ & & $0.163 \pm 0.003$ \\
\hline
\end{tabular}


Table.4 Anticancer activity of the Anacaridium occidentale (leaves and bark) extracts on Vero, L929, A549, MCF 7, U87 and Hela cell lines

\begin{tabular}{|c|c|c|c|c|c|c|c|c|}
\hline $\begin{array}{c}\text { Description } \\
\text { of the } \\
\text { samples }\end{array}$ & Extract & $\begin{array}{c}\text { Vero } \\
\text { CTC }_{50} \\
(\mu \mathrm{g} / \mathrm{ml})\end{array}$ & $\begin{array}{c}\text { L929 } \\
\text { CTC }_{50} \\
(\mu \mathrm{g} / \mathrm{ml})\end{array}$ & $\begin{array}{c}\text { A549 } \\
\text { CTC }_{50} \\
(\mu \mathrm{g} / \mathrm{ml})\end{array}$ & $\begin{array}{c}\text { MCF - } 7 \\
\text { CTC }_{50} \\
(\mu \mathrm{g} / \mathrm{ml})\end{array}$ & $\begin{array}{c}\text { U87 } \\
\text { CTC }_{50} \\
(\mu \mathrm{g} / \mathrm{ml})\end{array}$ & $\begin{array}{c}\text { Hela } \\
\text { CTC }_{50} \\
(\mu \mathrm{g} / \mathrm{ml})\end{array}$ & $\begin{array}{c}\text { Average } \\
\text { CTC }_{50} \\
(\mu \mathrm{g} / \mathrm{ml})\end{array}$ \\
\hline \multirow{3}{*}{$\begin{array}{c}\text { Anacaridium } \\
\text { occidentale } \\
\text { Leaves } \\
\text { (AOL) }\end{array}$} & Hexane & $158.83 \pm 3.3$ & $227.39 \pm 4.2$ & $201.15 \pm 4.9$ & $302.77 \pm 4.7$ & $119.78 \pm 2.5$ & $590.19 \pm 4.5$ & 303.47 \\
\hline & $\begin{array}{c}\text { Ethyl } \\
\text { Acetate }\end{array}$ & $318.01 \pm 4.8$ & $341.23 \pm 4.8$ & $159.04 \pm 0.7$ & $85.65 \pm 4.9$ & $83.64 \pm 4.4$ & $102.69 \pm 4.9$ & 107.75 \\
\hline & Methanol & $>1000$ & $274.27 \pm 4.7$ & $801.72 \pm 4.5$ & $397.72 \pm 3.9$ & $257.25 \pm 4.7$ & $579.28 \pm 4.1$ & 508.99 \\
\hline \multirow{3}{*}{$\begin{array}{c}\text { Anacaridium } \\
\text { occidentale } \\
\text { Bark } \\
\text { (AOB) }\end{array}$} & Hexane & $225.25 \pm 4.7$ & $291.83 \pm 4.4$ & $216.27 \pm 4.6$ & $111.73 \pm 1.0$ & $294.57 \pm 4.8$ & $659.56 \pm 4.8$ & 320.53 \\
\hline & $\begin{array}{c}\text { Ethyl } \\
\text { Acetate }\end{array}$ & $261.87 \pm 3.9$ & $307.64 \pm 4.8$ & $359.83 \pm 4.7$ & $99.73 \pm 1.8$ & $152.97 \pm 4.7$ & $224.33 \pm 1.9$ & 209.21 \\
\hline & Methanol & $>1000$ & $659.19 \pm 3.9$ & $>1000$ & $693.96 \pm 1.5$ & $>1000$ & $610.49 \pm 4.8$ & 652.22 \\
\hline
\end{tabular}

Footnote: The average $\mathrm{CTC}_{50}$ is the mean of cancer cell lines from the column 5 to 8 i.e., A549 cell line to Hela cell line.

Table.5 Structure-Activity Relationship (SAR) of the three potent phytomolecules namely

Zoapatanolide A, Agasthisflavone and Anacardic acid were docked with the target molecule p38 $\alpha$ MAP kinase

\begin{tabular}{|c|c|c|c|c|c|}
\hline \multirow[t]{2}{*}{$\begin{array}{l}\text { Name of the } \\
\text { Biomarker }\end{array}$} & \multirow[t]{2}{*}{$\begin{array}{l}\text { Name of the } \\
\text { Compound }\end{array}$} & \multicolumn{2}{|c|}{$\begin{array}{c}\text { Details of H- } \\
\text { bond interaction }\end{array}$} & \multirow{2}{*}{$\begin{array}{c}\text { Atomic } \\
\text { contact } \\
\text { Energy }(\mathrm{ACE}) \\
\text { Values }\end{array}$} & \multirow[t]{2}{*}{$\begin{array}{l}\text { Amino acid residues on docked } \\
\text { domains }\end{array}$} \\
\hline & & $\begin{array}{l}\text { No. of } \\
\text { bond }\end{array}$ & $\begin{array}{l}\text { Bond } \\
\text { energy }\end{array}$ & & \\
\hline \multirow{4}{*}{$\begin{array}{l}\text { p38a MAP } \\
\text { kinase } \\
\text { (4FA2) }\end{array}$} & Zoapatanolide A & 0 & 0 & -294.99 & $\begin{array}{l}\text { Val 38, Ala 51, Met 109, Gly 110, } \\
\text { Ala 111, Ala 157, Leu 167, Phe } \\
\text { 169, Leu 171 }\end{array}$ \\
\hline & Agasthisflavone & 9 & $\begin{array}{c}-0.13 \\
2.62 \\
-2.5 \\
-0.38 \\
6.73 \\
0.86 \\
3.64 \\
-0.033 \\
-1.906\end{array}$ & -345.06 & $\begin{array}{l}\text { Val 30, Val 38, Lys 53, Leu 104, } \\
\text { Thr 106, Leu 108, Met 109, Gly } \\
\text { 110, Ala 111, Asp 112, Asn 115, } \\
\text { Ser 154, Ala 157, Leu } 167\end{array}$ \\
\hline & Anacardic acid & 3 & $\begin{array}{l}-0.187 \\
-104 \\
-0.218\end{array}$ & -302.80 & $\begin{array}{l}\text { Ala 51, Lys 53, Leu 104, Thr 106, } \\
\text { Leu 108, Met 109, Gly 110, Ala } \\
\text { 111, Glu 160, Leu 167, Phe } 169\end{array}$ \\
\hline & $\begin{array}{c}\text { Doxorubicin } \\
\text { (standard drug) }\end{array}$ & 2 & $\begin{array}{l}-1.60 \\
-0.13\end{array}$ & -409.14 & $\begin{array}{l}\text { Ala } 51 \text {, Lys 53, Thr 106, Leu } \\
\text { 108, Met 109, Gly 110, Ala 111, } \\
\text { Asp 112, Ser 154, Leu 167, Leu } \\
\text { 171, Phe } 169\end{array}$ \\
\hline
\end{tabular}

Fig.1 Chemical structure of the molecules: A- Zoapatanolide A, B- Agasthisflavone, 


\section{C- Anacardic acid}

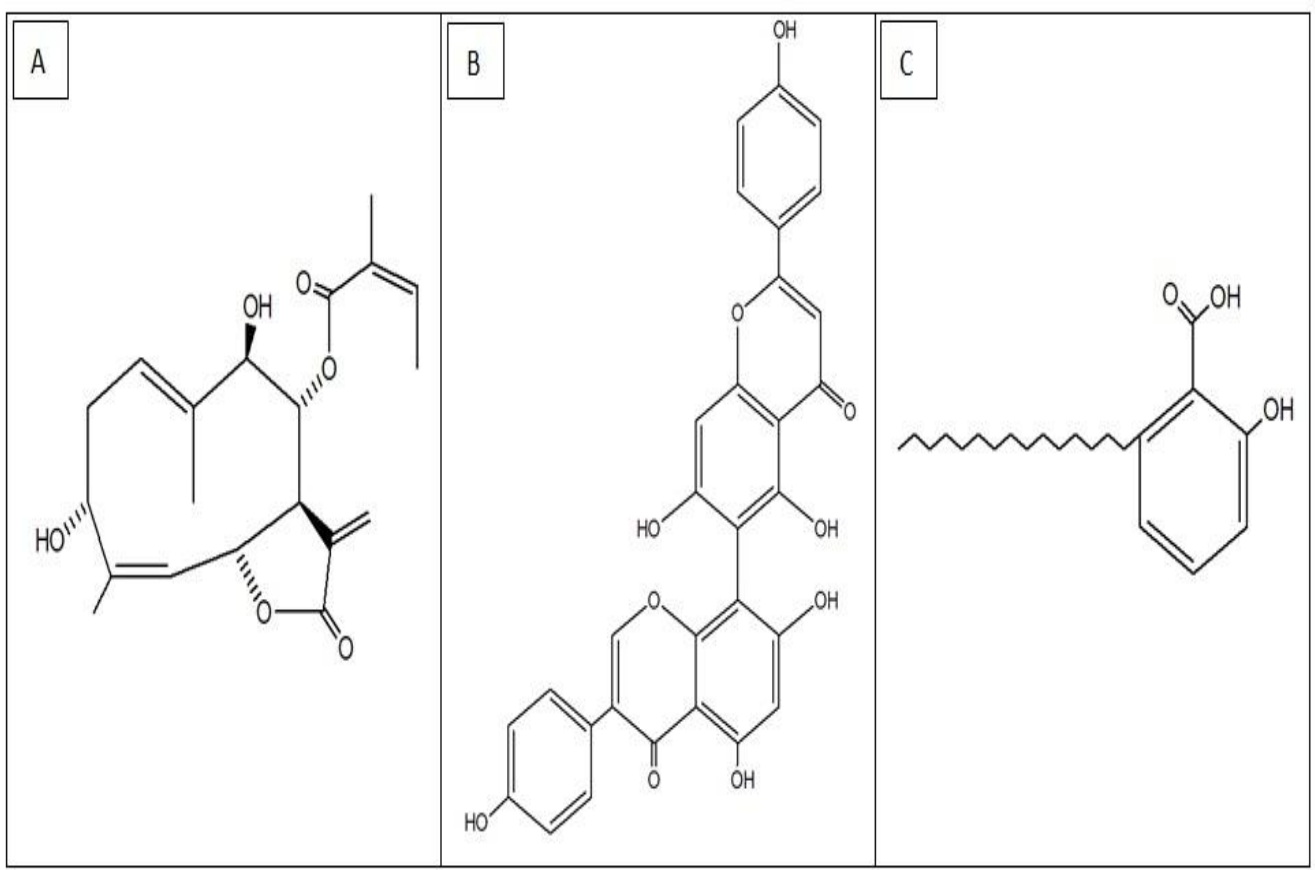

Fig.2 Molecular docking of the phytoligands with the target for understanding structure-activity relationship studies (1). p38 $\alpha$ MAPK \& Zoapatanolide A, (2). p38 $\alpha$ MAPK \& Agasthisflavone, (3). p38 $\alpha$ MAPK \& Anacardic acid (4). p38 $\alpha$ MAPK \& Doxorubicin

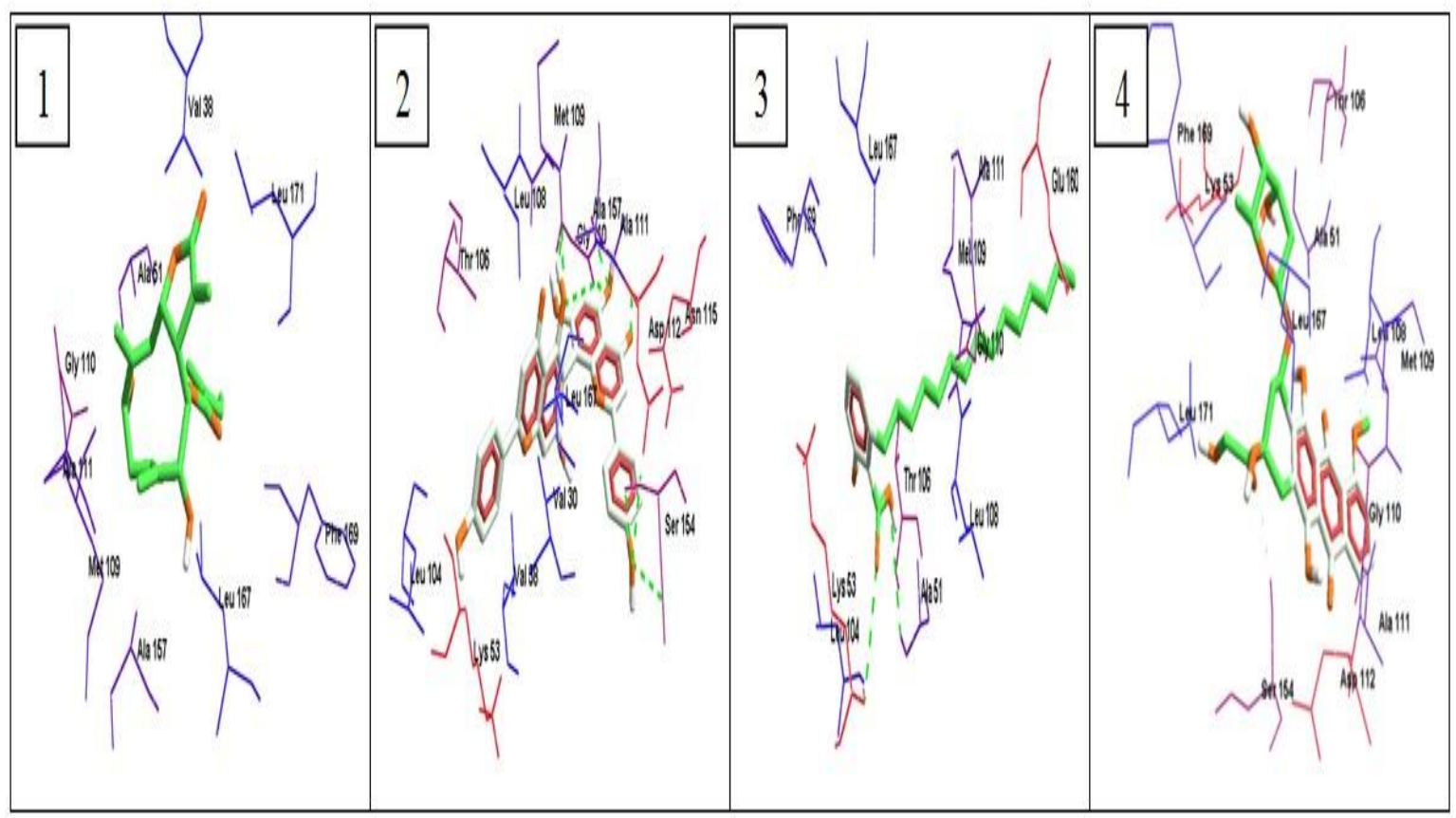


Fig.3 Summary of the probable mode of action of the phytoinhibitors on cancer molecular targets

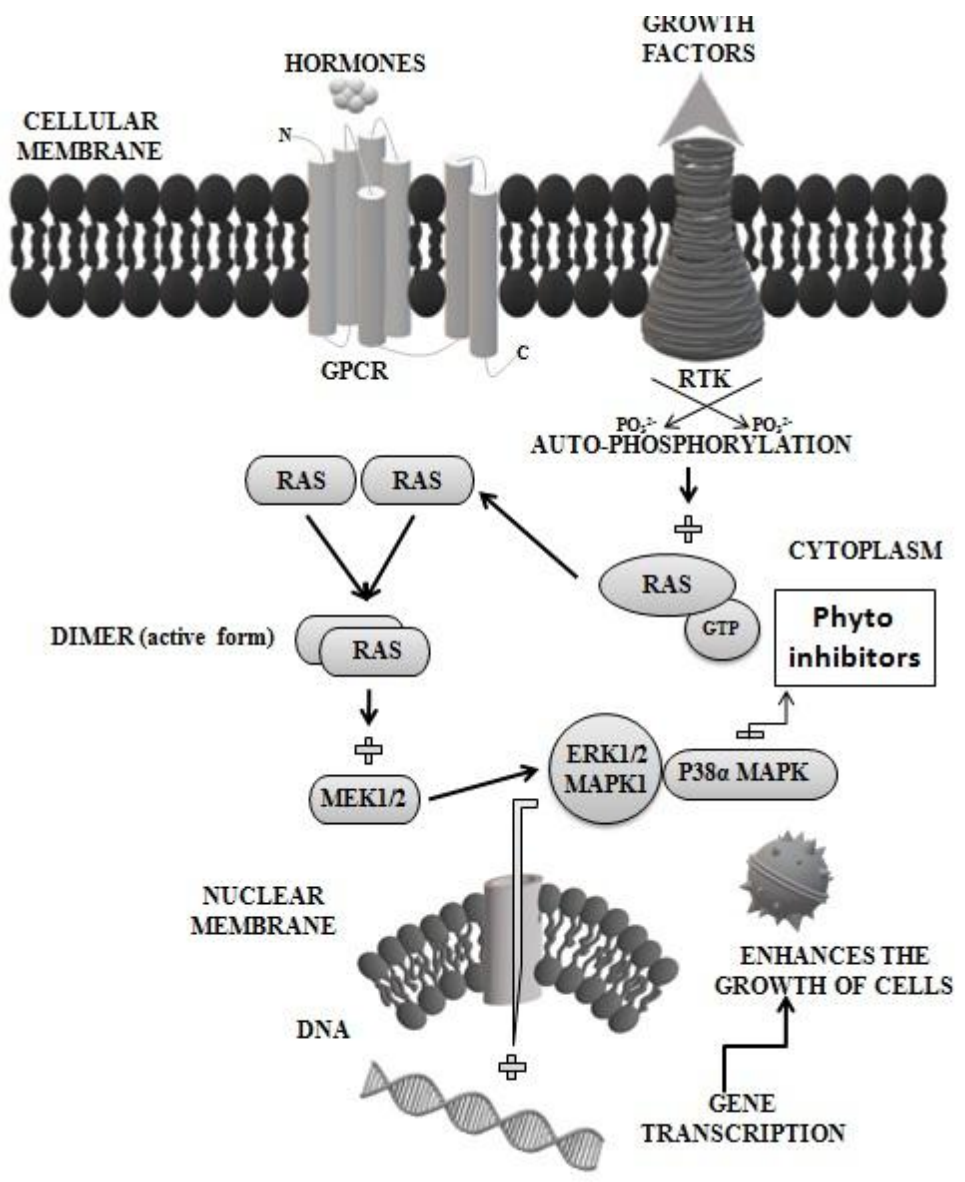

p38 mitogen-activated protein kinase also known as cytokinin specific binding protein are serine/threonine protein kinases. The human p38 MAP kinase is subdivided into four isoforms $\mathrm{p} 38 \alpha, \mathrm{p} 38 \beta, \mathrm{p} 38 \gamma$ and $\mathrm{p} 38 \delta$, among which $\mathrm{p} 38 \alpha$ is found to be the best characterized isoforms. p38 MAP kinase are responsible to phosphorylate nuclear as well as cytoplasmic targets (Sebolt-Leopold et al., 2000). p38 MAP kinase is a signalling pathway that is responsible to regulate a complicated network of proteins that are involved in various functions like cellular activities, cell-differentiation, apoptosis, cell cycle arrest, tumor suppression, cell senescence and cytokine synthesis (Olson et al., 2004); (Pearson et al., 2001).
The results from the structure-activity relationship studies revealed that among the known phytobioactives from Anacardium occidentale namely zoapatanolide A, Agasthisflavone and anacardic acid compared to the standard drug doxorubicin, Agasthisflavone had a better atomic contact energy (ACE) values of -345.06 (Table 5).

The same is evident from the docking posses (Fig.2). Various evidences by researchers prove that $\mathrm{p} 38 \alpha$ MAP kinase play a major role in cancer (Chen et al., 2009).

Since p38 $\alpha$ MAPK is highly expressed in cancer all the phytomolecules were tested on the viability of the cancer cell lines (Fig.3). In conclusion, overall study reflects to identify 
naturally occurring phytomolecules from Anacardium occidentale that would act as therapeutic agent to treat cancer and that would also exhibit antioxidant activity. Thus aiming at newer and potent drug targets with lesser or no toxicity. Further, work will be extrapolated in elucidation of pure phytobioactives and understanding the precise mechanism of action against cancer therapeutics.

\section{References}

Ashraf MS, Rathinasamy K. Antibacterial and anticancer activity of the purified cashew nut shell liquid: implications in cancer chemotherapy and wound healing. Nat Prod Res. 2018; 32(23): 2856-2860.

Ashwini Prasad, Aishwarya Tripurasundari Devi, Nagendra Prasad MN, Farhan Zameer, Govindaraju Shruthi, Chandan Shivamallu (2019). Phyto-Antibiofilm Elicitors as potential inhibitors of Helicobacter pylori. 3 Biotech. 9:53 doi.org/10.1007/s13205-019-1582-2.

Aslani Banafsheh Amir, Ghobadi Sirous, Studies on oxidants and antioxidants with a brief glance at their relevance to the immune system, Life Sciences (2016).

Bhavani, M. B., Shareef, I. M., Sampath Kumara, K. K., Nethra, N. S., \& Leelavathi, S. (2013). Evaluation of in Vitro Antioxidant activity of a Few Wild Cucurbitaceae Plants against Cancer.

Bray F, Ferlay J, Soerjomataram I, Siegel RL, Torre LA, Jemal A. Global cancer statistics 2018: GLOBOCAN estimates of incidence and mortality worldwide for 36 cancers in 185 countries. CA Cancer J Clin, 2018, 68(6): 394-424.

Chen L, Mayer JA, Krisko TI, Speers CW, Wang T, Hilsenbeck SG, Brown PH. Inhibition of the p38 kinase suppresses the proliferation of human ER-negative breast cancer cells. Cancer Res. 2009; 69:88538861.

Da Silva RA, Dihl RR, Nascimento e Santos D, de Abreu BR, de Lima A, de Andrade $\mathrm{HH}$, Lehmann M. Evaluation of antioxidant and mutagenic activities of honey-sweetened cashew apple nectar. Food Chem Toxicol, 2013, 62:61-7.

Elizabeth $\mathrm{K}$ and Rao MNA. Oxygen radical scavenging activity of Curcumin, International Journal of Pharmacology. 1990, 58; 237-240.

Francis D and Rita L. Rapid "colorometric assay for cell growth and survival modifications to the tetrazolium dye procedure giving improved sensitivity and reliability". Journal of Immunological Methods, 1986; 89: 271-277.

Garrat DC. The Quantitative Analysis of Drugs. $3^{\text {rd }}$ Ed. Chapman and Hall Ltd, Japan, 1964; p.456-58.

Gezici S, Sekeroglu N. Current Perspectives in the Application of Medicinal Plants Against Cancer: Novel Therapeutic Agents. Anticancer Agents Med Chem. 2019;19(1):101-111.

Iniyan, G. Tamil., Dineshkumar, B., Nandhakumar, M., Senthilkumar, M., Mitra, A. (2011) In vitro study on $\alpha$ amylase inhibitory activity of an Indian medicinal plant, Phyllanthusamarus. IP. Vol 42, pp 280-282.

Jaishree Vaijanathappa, Shrishailappa Badami., Sauresh Bhojaraj., (2008) In Vitro antioxidant activity of enicostemma axillare. J. Health Science. Vol 54 (5), pp $524-528$.

Madhusudan M, Farhan Zameer, Akhilender Naidu, Dhananjaya BL and Raghavendra Hegdekatte (2015). Contribution of Withania somnifera against Platelet Aggregation and Inflammatory Enzymes and Screening of Bioactives by Molecular Docking. Pharmaceutical Biology. 54(9) 1-6.

Nenadis $\mathrm{N}$, Wang L, Tsimidou $\mathrm{M}$ and Zhang $\mathrm{H}$. Estimation of scavenging activity of phenolic compounds using the ABTS assay, Journal of Agricultural Food Chemistry. 2004, 52; 4669-4674.

Niu N, Wang L. In vitro human cell line models to predict clinical response to anticancer drugs. Pharmacogenomics, 2015, 16(3):273-85

Nupur Joshi, Shashank Bhatt, Dhyani, \& Nain Jyoti. (2013). Phytochemical screening of secondary metabolites of Argemone 
mexicana Linn. Flowers. International Journal of Current Pharmaceutical Research. 5. 144-147.

Olson JM, Hallahan AR. p38 MAP kinase: a convergence point in cancer therapy. Trends Mol Med. 2004; 10: 125-9.

Pearson G, Robinson F, Beers Gibson T, Xu BE, Karandikar M, Berman K, Cobb MH.Mitogen-activated protein (MAP) kinase pathways: regulation and physiological functions. Endocr Rev. 2001, 22(2):153-183.

Praveen Kumar K, Farhan Zameer, Satish Kumar Murari (2018). Structural-functional insights and antidiabetic studies on Dipeptidyl peptidase-4 (DPP-4) binding to catechin from Withania somnifera. Biomedical Research. 29-18-922.

Re R, Pellegrini M, Proteggente A, Pannala A and Yang M. Rice EC Antioxidant activity applying an improved ABTS radical cationdecolocrisation assay, Free Radical Biology and Medicine. 1999, 26; 12311237.

Salehi B, Gultekin-ozguven M, Kirkin C, et al. Anacardium Plants: Chemical, Nutritional Composition and Biotechnological Applications. Biomolecules. 2019; 9(9): 465.

Sathya RK, Swamy J, Ramesh ST, Dhananjaya MC, Nanjundaswamy A, Bhadraiah HK, Farhan Zameer, Subbaiah GK, Subbegowda RK (2014). Anti-Cancer Activity of 2,4-Disubstituted Thiophene Derivatives: Dual Inhibitors of Lipoxygenase and Cyclooxygenase. Medicinal Chemistry. 111; 462-472.

Sathya RK, Swamy Jagadish, Kyathegowd- anadoddi Srinivas Balaji, Farhan Zameer, Toreshettahally Ramesh Swaroop, Chakrabhavi Dhanajaya Mohan, Jayarama Shankar, Kanchugarakoppal Subbegowda Rangappa (2016). 3,5-Disubstituted Isoxazole Derivatives: Potential Inhibitors of Inflammation and Cancer. Inflammation. 39(1):269-80.

SchuÈttelkopf, A.W., and Van Aalten, D.M. (2004). PRODRG: a tool for highthroughput crystallography of proteinligand complexes. Acta Crystallogr. 60: 1355-1363.

Sebolt-Leopold JS. Development of anticancer drugs targeting the MAP kinase pathway. Oncogene 2000, 19:6594-6599.

Su WC, Lin YF, Yu XP, et al. MitochondriaAssociated Apoptosis in Human Melanoma Cells Induced by Cardanol Monoene from Cashew Nut Shell Liquid. J Agric Food Chem. 2017; 65(28): 56205631 .

Taiwo BJ, Fatokun AA, Olubiyi OO, BamigboyeTaiwo OT, van Heerden FR, Wright CW. Identification of compounds with cytotoxic activity from the leaf of the Nigerian medicinal plant, Anacardium occidentale L. (Anacardiaceae). Bioorg Med Chem. 2017; 25(8): 2327-2335.

Thomsen R, Christensen MH. 2006. MolDock: a new technique for high accuracy molecular docking. J Med Chem. 49: 3315-3321.

Zhizhunang, Xiao, Reginald, Storms., Adrian, Tsang. (2010) A quantitative starchiodine method for measuring alphaamylase and glucoamylase activities. Analytical Biochemistry. Vol 8, pp 1-4.

\section{How to cite this article:}

Amar Shankar, S. M. Gopinath and Ismail Shareef, M. 2020. Phytosensitization and Cytotoxic Studies of Anacardium occidentale L. on Cancer Cell Lines - A Herbaceutical Approach. Int.J.Curr.Microbiol.App.Sci. 9(02): 1589-1603. doi: https://doi.org/10.20546/ijcmas.2020.902.183 